\title{
The Metabolism of Acetaldehyde in Mammalian Tissues
}

\author{
REACTIONS IN RAT-LIVER SUSPENSIONS UNDER AEROBIC CONDITIONS
}

\author{
By F. LUNDQUIST,* ULLA FUGMANN, H. RASMUSSEN AND I. SVENDSEN \\ Department of Forensic Medicine, University of Copenhagen, Denmark
}

(Received 18 December 1961)

Under anaerobic conditions acetaldehyde added to rat-liver suspensions is metabolized by a coupled oxidation-reduction between aldehyde dehydrogenase (Racker, 1949) (which oxidizes acetaldehyde to acetic acid) and alcohol dehydrogenase (which reduces some of the aldehyde to ethanol). Condensation reactions seem to play no measurable role in this tissue at concentrations below $\mathbf{0 . 3} \mathbf{~ m M}$ (Lundquist, Fugmann, Kläning \& Rasmussen, 1959).

In the presence of oxygen the participation of autoxidizable flavoproteins could be imagined to be of importance for the oxidation of acetaldehyde to acetate by liver preparations. Xanthine oxidases from pig liver (Corran, Dewan, Gordon \& Green, 1939), calf liver (Kielley, 1955) and rat liver (Richert, Vanderlinde \& Westerfeld, 1950) catalyse the oxidation of aldehydes, and specific aldehyde oxidases have been prepared from pig liver by Gordon, Green \& Subrahmanyan (1940) and Mahler, Mackler, Green \& Bock (1954), and from horse liver by Carpenter (1951). The quinine oxidase from rabbit liver discovered by Knox (1946) also attacks aldehydes.

In the present investigation the change in metabolism of acetaldehyde in liver suspensions, which takes place on admission of oxygen, was studied. A preliminary account of some of this work has been published (Lundquist, Fugmann \& Rasmussen, 1958).

\section{EXPERIMENTAL}

Materials. $\mathrm{NAD}^{+}, \mathrm{NADH}$, yeast alcohol dehydrogenase, horse-liver alcohol dehydrogenase, muscle lactate dehydrogenase, and cytochrome $c$ were obtained from C. F. Boehringer und Soehne, G.m.b.M., Mannheim, Germany. Liver aldehyde dehydrogenase was prepared according to Racker (1949). This preparation was also used as a source of liver lactate dehydrogenase. 2-Amino-6-formyl-4-hydroxypteridine was prepared from folic acid (Hofmann-La Roche and Co. Ltd.) by the procedure of Waller et al. (1950). 2-nHeptyl-4-hydroxyquinoline $N$-oxide was given by Dr J. W. Lightbown, London, antimycin A by Dr H. A. Lardy, Madison, Wis., U.S.A., and xanthine oxidase (from cream)

* Present address: Department of Biochemistry, University of Copenhagen, Juliane Maries Vej 30, Copenhagen, Denmark. by $\mathrm{Dr}$ H. Klenow, Copenhagen. Other chemicals were analytical-grade products.

Experimental technique and analytical methods. The experimental procedure was essentially as described by Lundquist et al. (1959). Rat-liver suspensions were prepared by disintegration of a weighed amount of fresh liver in a $60 \mathrm{ml}$. Potter-Elvehjem homogenizer with 10 vol. of a solution containing $\mathrm{KCl}(90 \mathrm{mM}), \mathrm{KH}_{2} \mathrm{PO}_{4}(14 \mathrm{mM})$ and $\mathrm{Na}_{2} \mathrm{HPO}_{4}(41 \mathrm{~mm})$. Nicotinamide (final concn. $20 \mathrm{~mm}$ ) was added to inhibit $\mathrm{NAD}^{+}$glycohydrolase.

In the apparatus described by Lundquist et al. (1959) liver suspension $(40-50 \mathrm{ml}$.) was incubated with acetaldehyde (initial concn. $300 \mu \mathrm{M}$ ). Oxygen, air from a pressure line, or oxygen-nitrogen mixtures were passed through the apparatus at a rate of $200 \mathrm{ml} . / \mathrm{min}$. for $5 \mathrm{~min}$. while temperature equilibration took place and before addition of acetaldehyde. The temperature in all experiments was $21^{\circ}$.

Samples $(3 \mathrm{ml}$.$) of the suspension were deproteinized$ with metaphophoric acid at well-defined intervals (generally $1 \mathrm{~min}$.). The neutralized filtrate was used for the determination of ethanol, acetaldehyde, $\mathrm{NAD}^{+}$and NADH as described by Lundquist et al. (1959). In all cases where inhibitors were used the effect of these on the analytical methods was examined. Analyses of known amounts of ethanol and acetaldehyde added to the suspensions immediately before deproteinization were included as controls in all experiments.

\section{RESULTS}

Two characteristic changes were observed in the metabolism of acetaldehyde when oxygen was admitted to the liver suspension. The rate of ethanol formation was much decreased and the 'aldehyde activity' (the rate of aldehyde disappearance corrected for the amount reduced to ethanol) was increased significantly. Fig. 1 shows a typical aerobic experiment.

Ethanol formation in liver suspensions (conen. of added $\mathrm{NAD}^{+}$about $200 \mu \mathrm{M}$ ) was $0 \cdot 11 \pm 0.04 \mu$ mole/min./g. of fresh liver (mean \pm S.D. of 23 experiments) compared with $0 \cdot 36 \mu \mathrm{mole} / \mathrm{min}$./g. of liver under anaerobic conditions (Lundquist et al. 1959). The formation of ethanol was further decreased when cytochrome $c$ was added to the tissue preparation at a concentration of $100 \mu \mathrm{M}$. In some experiments it was immeasurably small. The average value for the formation of ethanol in 5 experiments in the presence of cytochrome $c$ was $0.04 \mu \mathrm{mole} / \mathrm{min} . / \mathrm{g}$. of tissue. Addition of cyto- 
chrome $c$ did not influence the 'aldehyde activity'. Thus in a typical experiment 'aldehyde activity' was $0.45 \mu \mathrm{mole} / \mathrm{min}$., whereas ethanol formation was $0.18 \mu \mathrm{mole} / \mathrm{min}$. After addition of cytochrome $c$ to a final concentration of $100 \mu \mathrm{M}$, 'aldehyde activity' was $0.44 \mu \mathrm{mole} / \mathrm{min}$. and ethanol formation $0.04 \mu \mathrm{mole} / \mathrm{min}$.

The 'aldehyde activity' in aerobic experiments was significantly higher than in anaerobic experiments. An average value ( \pm S.D.) of $0.40 \pm 0.07 \mu$ $\mathrm{mole} / \mathrm{min}$./g. of fresh liver was found in 22 experiments carried out under the conditions described. In anaerobic experiments aldehyde activities of 0.23 (without pyruvate) and 0.30 (with $500 \mu \mathrm{M}$-pyruvate added) were recorded by Lundquist et al. (1959).

Influence of oxygen pressure. Fig. 2 shows the results of a series of experiments with varying oxygen pressure performed on a single homogenate prepared from the livers of ten rats. Suitable mixtures of nitrogen and oxygen were passed through the tissue suspension before and during the actual experiments. The experiments at low oxygen pressure were performed first. In other experiments the aldehyde-oxidizing enzyme system tended to deteriorate with time. In one experiment, for instance, an 'aldehyde activity' of $0.51 \mu \mathrm{mole} /$

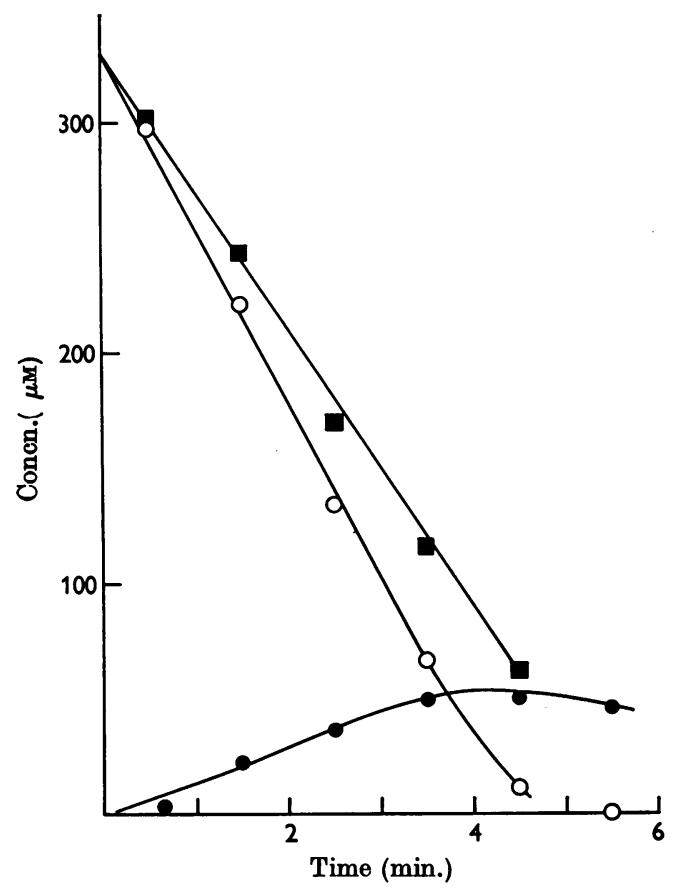

Fig. 1. Typical aerobic experiment. The conditions were as described in the Experimental section. $O$, Concn. of acetaldehyde; , concn. of ethanol; $\square$, concn. of ethanol + acetaldehyde (the negative slope of this curve represents the 'aldehyde activity'). min./g. of liver was found immediately after homogenization; after storage of the homogenate in ice for $2.5 \mathrm{hr}$. the 'aldehyde activity' had dropped to $0.46 \mu \mathrm{mole} / \mathrm{min}$./g.

The slight decrease in 'aldehyde activity' at higher oxygen pressure may therefore have been caused by deterioration of the tissue preparation. The differences are, however, barely significant.

Influence of oxidized nicotinamide-adenine dinucleotide concentration. The difference in magnitude of the 'aldehyde activity' in anaerobic and aerobic experiments was more marked at low concentrations of $\mathrm{NAD}^{+}$(i.e. without $\mathrm{NAD}^{+}$added) than at higher concentrations. Only at very low $\mathrm{NAD}^{+}$ concentrations was the aerobic aldehyde activity significantly decreased (Table 1).

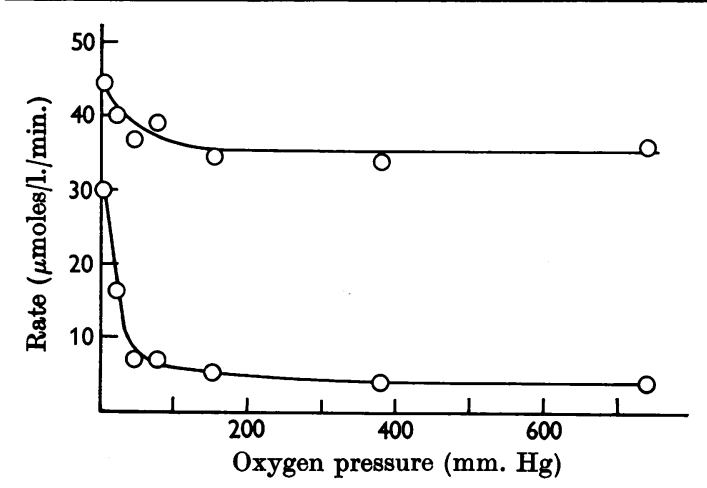

Fig. 2. Dependence of 'aldehyde activity' and ethanol formation on the oxygen pressure. Upper curve, aldehyde activity, lower curve, ethanol production. The lowest oxygen pressure used $(5 \mathrm{~mm}$. $\mathrm{Hg})$ was sufficient to secure maximal aldehyde activity in spite of the high steady-state concentration of $\mathrm{NADH}$, which results in increased ethanol formation at the low oxygen pressures.

Table 1. Dependence of 'aldehyde activity' on the concentration of oxidized nicotinamide-adenine dinucleotide

The same homogenate was employed in all eight experiments. Oxygen was the gas phase in the aerobic experiments. Pyruvate (initial concn. $400 \mu \mathrm{M}$ ) was added in each of the anaerobic experiments. Ethanol formation in both series of experiments showed no significant variation (range $0.01-0.09 \mu \mathrm{mole} / \mathrm{min} . / \mathrm{g}$. of fresh tissue). —, Not measured.

$\begin{array}{cccc}\begin{array}{c}\text { Experimental } \\ \text { conditions }\end{array} & \begin{array}{c}\text { Concn. of } \\ \text { NAD }^{+} \\ (\mu \mathrm{M})\end{array} & \begin{array}{c}\text { Concn. of } \\ \text { NADH } \\ (\mu \mathrm{M})\end{array} & \begin{array}{c}\text { 'Aldehyde } \\ \text { activity' } \\ (\mu \text { mole/min./ } \\ \text { g. of liver })\end{array} \\ \text { Anaerobic } & 26 & 12 & 0 \cdot 055 \\ & 57 & 13 & 0 \cdot 19 \\ & 138 & 16 & 0 \cdot 25 \\ \text { Aerobic } & 289 & 24 & 0 \cdot 29 \\ & 23 & - & 0 \cdot 23 \\ & 56 & - & 0.34 \\ & 143 & - & 0.34 \\ & 334 & - & 0.33\end{array}$


The concentration of $\mathrm{NADH}$ in aerobic experiments was less than $5 \mu \mathrm{M}$ and could not be accurately determined by the method used.

Inhibition experiments. To decide whether the increase in 'aldehyde activity' observed in the presence of oxygen was brought about through the activity of flavoprotein enzymes, such as xanthine oxidase, aldehyde oxidase or others, attempts were made to inhibit this activity by means of 2 -amino6-formyl-4-hydroxypteridine (pteridyl aldehyde), which inhibits these enzymes (Lowry, Bessey \& Crawford, 1949; Kalckar, Kjeldgaard \& Klenow, 1950). Table 2 shows examples of such experiments. The small inhibition observed in the presence of pteridyl aldehyde in a number of experiments either at the acetaldehyde concentration generally used $(300 \mu \mathrm{M})$ or at concentrations 20 times as high were not considered significant. The concentration of inhibitor used (about $100 \mu \mathrm{M}$ ) was higher than necessary to cause complete inhibition of milk xanthine oxidase. The inhibitory activity of the preparation used was checked with xanthine oxidase by the assay procedure of Mackler, Mahler $\&$ Green (1954). A concentration of about $20 \mu \mathrm{M}$ caused complete inhibition. Experiments were also made with other inhibitors in an attempt to clarify the mechanism of the increased aldehyde activity under aerobic conditions.
Antimycin A $(4 \mu \mathrm{g} . / \mathrm{ml}$.) and 2-n-heptyl-4hydroxyquinoline $N$-oxide $(10 \mu \mathrm{M})$, which are known to inhibit the mitochondrial electron transport at the level of cytochrome $b$ (Potter \& Reif, 1952; Jackson \& Lightbown, 1958), were without appreciable effect on aldehyde activity or ethanol formation, whereas azide, which inhibits cytochrome $c$ oxidase, caused considerable inhibition (Table 3). The observation that ethanol formation was not increased in experiments in which azide was added may be explained by the inhibition of alcohol dehydrogenase by azide (Table 4). Aldehyde dehydrogenase prepared from liver according to Racker (1949) is not influenced by azide (Table 4). The stronger inhibition of acetaldehyde reduction than of ethanol oxidation may be due to the fact that the concentration of coenzyme was 9 times as high in the oxidation experiments. Experiments with other inhibitors (8-hydroxyquinoline and $o$-phenanthroline) showed the same phenomenon. Table 4 also shows the effect of $p$ chloromercuribenzoate and $p$-chloromercuribenzenesulphonate on the two enzymes. These SHreagents have been found to inhibit the NADHcytochrome $c$ reductase of microsomes (Stritmatter \& Velick, 1956) at concentrations of $10 \mu \mathrm{M}$. Experiments with homogenates with both substances at concentrations of up to $60 \mu \mathrm{M}$, however,

Table 2. Inhibition experiments with 2-amino-6-formyl-4-hydroxypteridine

In the first four experiments $\mathrm{NAD}^{+}$was added (total concn. 200-250 $\mu \mathrm{M}$ ). In the last two experiments the total $\mathrm{NAD}^{+}$concentration was 30-40 $\mu \mathrm{M}$. The experimental procedure was as described in Experimental section. Oxygen was used for gas phase.

\begin{tabular}{|c|c|c|c|}
\hline $\begin{array}{l}\text { Experimental } \\
\text { conditions }\end{array}$ & Additions & $\begin{array}{c}\text { Concn. of } \\
\text { aldehyde } \\
\text { (mM) }\end{array}$ & $\begin{array}{l}\text { 'Aldehyde } \\
\text { activity' } \\
\text { ( } \mu \text { mole/min./g. } \\
\text { of liver) }\end{array}$ \\
\hline $\begin{array}{l}\text { Anaerobic } \\
\text { Aerobic }\end{array}$ & $\begin{array}{l}\mathrm{NAD}^{+} \\
\mathrm{NAD}^{+}+\text {pyruvate }(400 \mu \mathrm{M}) \\
\mathrm{NAD}^{+} \\
\mathrm{NAD}^{+}+\text {pteridyl aldehyde }(100 \mu \mathrm{M})\end{array}$ & $\begin{array}{l}0 \cdot 3 \\
0 \cdot 3 \\
0 \cdot 3 \\
0 \cdot 3\end{array}$ & $\begin{array}{l}0 \cdot 13 \\
0 \cdot 25 \\
0 \cdot 37 \\
0 \cdot 34\end{array}$ \\
\hline & $\begin{array}{l}\text { None } \\
\text { Pteridyl aldehyde }(100 \mu \mathrm{M})\end{array}$ & $\begin{array}{l}3 \cdot 0 \\
\mathbf{3} \cdot 0\end{array}$ & $\begin{array}{l}0.74 \\
0.67\end{array}$ \\
\hline
\end{tabular}

Table 3. Influence of azide on aerobic 'aldehyde activity'

Experimental conditions were as described in the text.

\begin{tabular}{|c|c|c|c|}
\hline $\begin{array}{l}\text { Experimental } \\
\text { conditions }\end{array}$ & Additions & $\begin{array}{c}\text { 'Aldehyde } \\
\text { activity' } \\
\text { ( } \mu \mathrm{mole} / \mathrm{min} . / \mathrm{g} . \\
\text { of liver) }\end{array}$ & $\begin{array}{c}\text { Ethanol } \\
\text { formation } \\
\text { ( } \mu \text { mole } / \text { min. } / \mathrm{g} \\
\text { of liver) }\end{array}$ \\
\hline $\begin{array}{l}\text { Anaerobic } \\
\text { Aerobic } \\
\text { Aerobic }\end{array}$ & $\begin{array}{l}\text { None } \\
\text { None } \\
\text { Azide (20 mM) }\end{array}$ & $\begin{array}{l}0 \cdot 12 \\
0 \cdot 26 \\
0 \cdot 19\end{array}$ & $\begin{array}{l}0.15 \\
0.09 \\
0.07\end{array}$ \\
\hline $\begin{array}{l}\text { Anaerobic } \\
\text { Aerobic } \\
\text { Aerobic }\end{array}$ & $\begin{array}{l}\text { NAD }+(0.3 \mathrm{~mm}) \\
\text { NAD }+(0.3 \mathrm{~mm}) \\
\text { NAD }+(0.3 \mathrm{~mm})+ \\
\text { azide }(20 \mathrm{~mm})\end{array}$ & $\begin{array}{l}0 \cdot 15 \\
0.35 \\
0 \cdot 23\end{array}$ & $\begin{array}{l}0 \cdot 45 \\
0 \cdot 20 \\
0 \cdot 13\end{array}$ \\
\hline
\end{tabular}


Table 4. Effect of some inhibitors on purified aldehyde dehydrogenase from ox liver and crystalline alcohol dehydrogenase from horse liver

The experiments were made in the potassium chloride-phosphate buffer solution used for the liver suspensions (see Experimental section). Activity was measured by the rate of change of NADH concentration followed through the absorption at $340 \mathrm{~m} \mu$ : increase for aldehyde dehydrogenase and liver alcohol dehydrogenase with excess of ethanol, decrease with liver alcohol dehydrogenase and excess of aldehyde. The reaction velocities are expressed as percentages of the uninhibited reaction rate. The concentration of NADH in the experiments with acetaldehyde and alcohol dehydrogenase was $0.1 \mathrm{mM}$. The $\mathrm{NAD}^{+}$concn. in the other experiments was $0.9 \mathrm{~mm}$.

\begin{tabular}{|c|c|c|c|}
\hline \multirow[b]{2}{*}{ Inhibitor } & \multicolumn{2}{|c|}{ Liver alcohol dehydrogenase } & \multirow{2}{*}{$\begin{array}{c}\text { Liver aldehyde } \\
\text { dehydrogenase. } \\
\text { Aldehyde } \\
\text { oxidation }\end{array}$} \\
\hline & $\begin{array}{l}\text { Aldehyde } \\
\text { reduction }\end{array}$ & $\begin{array}{c}\text { Ethanol } \\
\text { oxidation }\end{array}$ & \\
\hline None & 100 & 100 & 100 \\
\hline Sodium azide $(20 \mathrm{~mm})$ & 12 & 86 & 100 \\
\hline$p$-Chloromercuribenzoate $(60 \mu \mathrm{M})$ & 0 & 0 & 0 \\
\hline$p$-Chloromercuribenzenesulphonate $(60 \mu \mathrm{M})$ & 0 & 0 & 0 \\
\hline$p$-Chloromercuribenzenesulphonate $(5 \mu \mathrm{M})$ & 100 & 100 & 100 \\
\hline
\end{tabular}

showed no decrease of the aerobic aldehyde activity. This lack of an inhibitory effect may have been due to inactivation of these inhibitors by $\mathrm{SH}$ groups in other proteins and in glutathione (cf. Stritmatter, 1958).

Amytal (5-ethyl-5-isopentylbarbiturate) inhibits the oxidation of $\mathrm{NADH}$ by flavoprotein in the mitochondrial respiratory chain (Ernster, Jalling, Löw \& Lindberg, 1955). In experiments in which Amytal was present (10 $\mathrm{mm}$ ) the rate of formation of ethanol from acetaldehyde increase to that observed under strictly anaerobic conditions. Thus in a typical experiment the formation of ethanol increased from 0.25 to $0.65 \mu \mathrm{mole} / \mathrm{min}$./g. of liver when Amytal was added; it was 0.57 $\mu \mathrm{mole} / \mathrm{min}$. in an anaerobic control experiment. The increase in ethanol formation in these experiments is in agreement with the inhibition of $\mathrm{NADH}$ removal through the respiratory chain. Under these conditions 'aldehyde activity' was not decreased, and a moderate increase was observed in most experiments. In one experiment, for instance, the control 'aldehyde activity' was $0.60 \mu \mathrm{mole} / \mathrm{min} . / \mathrm{g}$. of tissue, whereas after addition of Amytal a value of $0.75 \mu \mathrm{mole} / \mathrm{min} . \mathrm{g}$. was obtained. The corresponding rates of ethanol formation were $\mathbf{0 . 3 5}$ and $1.08 \mu \mathrm{moles} / \mathrm{min} . \mathrm{g}$. of fresh liver. However, the determination of 'aldehyde activity' under these conditions is not very precise because a large value for ethanol formation has to be subtracted from the total aldehyde disappearance. The latter is so rapid that only two or three points are obtained on the curve before the aldehyde is completely utilized. These experiments do not establish whether aldehyde dehydrogenation is in fact accelerated.

The influence of Amytal (10 mM) on a number of enzymes was determined at $\mathrm{pH} 7 \cdot 1$ in the buffer used for the liver experiments through spectrophotometric measurement of the reduction of
$\mathrm{NAD}^{+}$. No effect on the reaction velocity was observed for the following enzymes: yeast alcohol dehydrogenase, horse-liver alcohol dehydrogenase, ox-liver aldehyde dehydrogenase, muscle lactate dehydrogenase and liver lactate dehydrogenase.

\section{DISCUSSION}

The possibility that the increase in 'aldehyde activity' observed in the presence of oxygen was due to the activity of flavoprotein enzymes, which can react only in the presence of oxygen either directly or via the cytochrome c-cytochrome oxidase system (Lundquist et al. 1958), seems to have been excluded by experiments with inhibitors of flavoprotein enzymes.

That flavoprotein enzymes play no role at the low concentration of acetaldehyde $(300 \mu \mathrm{M}) \mathrm{em}$ ployed in most of these experiments can be explained by the rather high Michaelis constant of these enzymes. Thus Mackler et al. (1954) found the $K_{m}$ of milk xanthine oxidase to be about $20 \mathrm{~mm}$, and Gordon et al. (1940) found a $K_{m}$ of $7 \mathrm{~mm}$ for liver aldehyde oxidase with crotonaldehyde as substrate. Carpenter's (1951) data on the horseliver enzyme correspond to a $K_{m}$ about $10 \mathrm{~mm}$ for acetaldehyde. Even at the highest aldehyde concentration employed in our experiments $(6 \mathrm{mM})$ the velocity would be less than half maximal. Moreover, the experiments of Richert \& Westerfeld (1957) with rat-liver preparations similar to those used in the present work showed that, at an aldehyde concentration of $40 \mathrm{~mm}$, only a small fraction (less than $15 \%$ ) of the aldehyde removed could be accounted for through the activity of flavoprotein enzymes. Even if enzymes like those mentioned were present in human liver in very large quantities, the amount of acetaldehyde oxidized through this pathway would be negligible at the very low aldehyde concentration (less than $10 \mu \mathrm{M}$ ) en- 
countered in the blood during ethanol metabolism (Lundquist \& Wolthers, 1958).

The possibility that inhibition is brought about by NADH and released under aerobic conditions is ruled out by experiments with Amytal, where the formation of ethanol and consequently the concentration of NADH was as high as in the anaerobic experiments.

The possibility was considered that aldehyde dehydrogenase might form a complex with NADHcytochrome $c$ reductase with one or more NAD molecules in common. Mahler \& Elowe (1954) showed that cytochrome $c$ reductase reacts readily with the bound NADH of glyceraldehyde 3-phosphate dehydrogenase. The following reactions may account for the increase in acetaldehyde oxidation in the presence of oxygen. Aldehyde dehydrogenase is designated $\mathrm{E}_{1}$ and NADHcytochrome $c$ reductase $\mathrm{E}_{2}$.

$$
\begin{aligned}
& \mathrm{E}_{1}-\mathrm{NAD}^{+}+\text {acetaldehyde } \rightarrow \mathrm{E}_{1}-\mathrm{NADH}+\mathrm{H}^{+} \\
& \text {+acetate } \\
& \mathrm{E}_{1}-\mathrm{NADH}+\mathrm{E}_{2} \rightleftharpoons \mathrm{E}_{1}-\mathrm{NADH}-\mathrm{E}_{2} \\
& \begin{aligned}
\mathrm{E}_{1}-\mathrm{NADH}-\mathrm{E}_{2}+\mathrm{H}^{+}+2 \text { cyt. } c \text { (ox.) } \\
\rightarrow \mathrm{E}_{1}-\mathrm{NAD}^{+}-\mathrm{E}_{2}+2 \text { cyt. } c \text { (red.) }
\end{aligned}
\end{aligned}
$$

If dissociation of NADH from aldehyde dehydrogenase is the rate-limiting step in aldehyde dehydrogenation as it is for liver alcohol dehydrogenase (Theorell \& Chance, 1951), the overall velocity will be increased if the oxidation of the reduced complex $\mathrm{E}_{1}-\mathrm{NADH}-\mathrm{E}_{2}$ by cytochrome $c$ is faster than the aldehyde-dehydrogenation step.

The experiments with antimycin $\mathbf{A}$ and 2-nheptyl-4-hydroxyquinoline $N$-oxide, which are known to inhibit the mitochondrial oxidative chain at the level of cytochrome $b$, indicate that the mitochondrial pathway for the first steps of NADH oxidation is of small importance for the aerobic increment in 'aldehyde activity'. The observation that ethanol formation was not influenced in these experiments in spite of very high concentrations of inhibitors indicates that NADH can be effectively oxidized by a pathway which is not sensitive to these inhibitors. The lack of inhibition of the 'aldehyde activity' at high concentrations of Amytal also supports the conclusion that acceleration of acetaldehyde metabolism is not dependent on mitochondrial oxidation of NADH.

The most likely alternative pathway for the oxidation of NADH under aerobic conditions appears to be by way of the microsomal NADHcytochrome $c$ reductase, as only an insignificant fraction of the NADH-cytochrome c-reductase activity is found in solution in the cytoplasm (Hogeboom, 1949). According to Stritmatter \& Velick (1956) the microsomal enzyme is inhibited by $p$-chloromercuribenzoate, but unfortunately it was not possible to attain a well-defined concentration of the active form of this substance in the liver suspension, which would inhibit NADH-cytochrome $c$ reductase without inhibiting either aldehyde dehydrogenase or alcohol dehydrogenase.

Azide is known to inhibit cytochrome $c$ oxidase, and consequently most of the $\mathrm{NADH}$ oxidation. The observed inhibition by azide of the aerobic increment in 'aldehyde activity' was therefore to be expected.

The velocities of aldehyde oxidation observed in our rat-liver (and a few rabbit-liver) suspensions are in good agreement with those observed in perfused rabbit liver by Hald, Jacobsen \& Larsen (1949), who found a disappearance of 0.4-2 $\mu$ moles/ min./g. of liver. When our results were corrected to $37^{\circ}$ (cf. Lundquist et al. 1959) an average value of $1.1 \mu \mathrm{moles} / \mathrm{min}$./g. of liver was obtained. A few experiments on rabbit-liver homogenates gave values very similar to those with rat liver. The results of our experiments in vitro are also in agreement with those of Hald \& Larsen (1949) with intact rabbits given acetaldehyde by intravenous infusion.

\section{SUMMARY}

1. When acetaldehyde is added to rat-liver suspensions in potassium chloride-phosphate buffer under aerobic conditions the rate of disappearance of this substance corrected for the part which is reduced to ethanol (the 'aldehyde activity') is increased to nearly twice the value found under anaerobic conditions with the same concentration of $\mathrm{NAD}^{+}$.

2. Inhibition experiments suggest that the increased 'aldehyde activity' is not caused by autoxidizable flavoproteins.

3. The effect is not abolished by inhibitors of the respiratory chain between NADH and cytochrome $b$, but is strongly diminished by azide. The effect cannot be explained as release of an inhibition by NADH of the aldehyde dehydrogenation.

4. It is suggested that the increased 'aldehyde activity' under aerobic conditions may be caused by the formation of a complex between aldehyde dehydrogenase, microsomal NADH-cytochrome $c$ reductase and $\mathrm{NADH}$, which could be oxidized by cytochrome $c$. The dissociation of NADH from the aldehyde dehydrogenase, which might be the ratelimiting step, would thus be circumvented.

This investigation has been supported partly through a grant (to F.L.) from Statens almindelige Videnskabsfond.

\section{REFERENCES}

Carpenter, F. H. (1951). Acta chem. scand. 5, 406.

Corran, H. S., Dewan, J. G., Gordon, A. H. \& Green, D. E. (1939). Biochem. J. 33, 1694. 
Ernster, L., Jalling, O., Löw, H. \& Lindberg, O. (1955). Expt. Cell Res. Suppl. 3, 124.

Gordon, A. H., Green, D. E. \& Subrahmanyan, V. (1940). Biochem. J. 34, 764.

Hald, J., Jacobsen, E. \& Larsen, V. (1949). Acta pharmacol., Kbh., 5, 298.

Hald, J. \& Larsen, V. (1949). Acta pharmacol., Kbh., 5, 292.

Hogeboom, G. H. (1949). J. biol. Chem. 177, 847.

Jackson, F. L. \& Lightbown, J. W. (1958). Biochem. J. 69, 63.

Kalckar, H., Kjeldgaard, N. O. \& Klenow, H. (1950). Biochim. biophys. Acta, 5, 586.

Kielley, R. K. (1955). J. biol. Chem. 216, 405.

Knox, W. E. (1946). J. biol. Chem. 163, 699.

Lowry, O. H., Bessey, O. A. \& Crawford, E. J. (1949). J. biol. Chem. 180, 399.

Lundquist, F., Fugmann, U., Kläning, E. \& Rasmussen, H. (1959). Biochem. J. 72, 409.

Lundquist, F., Fugmann, U. \& Rasmussen, H. (1958). Abstr. 4th int. Congr. Biochem., Vienna, p. 58.
Lundquist, F. \& Wolthers, H. (1958). Acta pharmacol., Kbh., 14, 265.

Mackler, B., Mahler, H. R. \& Green, D. E. (1954). J. biol. Chem. 210, 149.

Mahler, H. R. \& Elowe, D. (1954). Biochim. biophys. Acta, 14, 100.

Mahler, H. R., Mackler, B., Green, D. E. \& Bock, R. M. (1954). J. biol. Chem. 210, 465.

Potter, V. R. \& Reif, A. E. (1952). J. biol. Chem. 194, 287.

Racker, E. (1949). J. biol. Chem. 177, 883.

Richert, D. A., Vanderlinde, R. \& Westerfeld, W. W. (1950). J. biol. Chem. 186, 261.

Richert, D. A. \& Westerfeld, W. W. (1957). J. biol. Chem. 227, 533.

Stritmatter, P. (1958). J. biol. Chem. 233, 748.

Stritmatter, P. \& Velick, S. F. (1956). J.biol. Chem. 221, 277.

Theorell, H. \& Chance, B. (1951). Acta chem. scand. 5, 1127 :

Waller, C. W., Goldman, A. A., Angier, R. B., Boothe, J. H., Hutchings, B. L., Mowat, J. H. \& Semb, J. (1950). J. Amer. chem. Soc. 72, 4630.

\title{
The Inhibitory Effect at the Hexokinase Level of Disulphides on Glucose Metabolism in Human Erythrocytes
}

\author{
By L. ELDJARN AND J. BREMER* \\ Institute of Clinical Biochemistry, Rikshospitalet, University of Oslo, Norway
}

(Received 18 December 1961)

We have previously shown that, provided that a suitable substrate such as glucose or adenosine is present, intact human erythrocytes reduce a number of disulphides with the appearance of the corresponding thiol in the suspending medium. This reduction probably takes place via spontaneous exchange reactions with glutathione, leading to the formation of oxidized glutathione, which in turn is reduced by glutathione reductase. However, when higher concentrations of the disulphide were used, cystamine and several cystamine derivatives completely inhibited their own reduction. When glucose was oxidized in the presence of methylene blue, the oxygen consumption was also inhibited by higher concentrations of cystamine. However, various disulphides showed different effects in these respects. Thus some disulphides were reduced both at low and high concentrations whereas others neither became reduced nor demonstrated any toxic effect (Eldjarn, Bremer \& Börresen, 1962).

Several explanations can be proposed for the

* Fellow of The Norwegian Cancer Society. 'disulphide poisoning' of erythrocytes. Higher concentrations of some disulphides are known to convert glutathione nearly quantitatively into the mixed disulphide form. Mixed disulphides with glutathione do not serve as substrates for glutathione reductase (Pihl, Eldjarn \& Bremer, 1957). The disulphide-reducing system of the erythrocytes may thus be inhibited by the removal of its substrate (oxidized glutathione). However, preliminary findings did not support such a mechanism (Eldjarn et al. 1962).

In this paper we demonstrate that the 'disulphide poisoning' of erythrocytes can be ascribed to a reversible block of glucose utilization at the hexokinase level. This block is not due to a shortage of ATP or to an accumulation of glucose 6-phosphate. Despite the fact that many erythrocyte enzymes are usually classified as SHenzymes, the experiments show that these other enzymes of the oxidative pentose shunt and of the Embden-Meyerhof glycolytic pathway are probably not inhibited in 'disulphide poisoning'. Also the glutathione-reductase system is most probably functionally intact. The inhibition of the disul- 